Check for updates

Cite this: RSC Adv., 2017, 7, 26478

Received 20th April 2017

Accepted 8th May 2017

DOI: $10.1039 / c 7 r a 04443 g$

rsc.li/rsc-advances

\section{Three Pt(II) complexes based on thiosemicarbazone: synthesis, HSA interaction, cytotoxicity, apoptosis and cell cycle arrest $\uparrow$}

\author{
Xu-Dong Lin, (D) $t^{a}$ Ya-Hong Liu, $t^{a}$ Cheng-Zhi Xie, (D) a Wei-Guo Bao, Jun Shen (D) *b \\ and Jing-Yuan $X u^{* a}$
}

Three thiosemicarbazone-based platinum(II) complexes [Pt(MH-TSC)Cl] (1), [Pt(ME-TSC)Cl] (2) and $\left[\mathrm{Pt}(\mathrm{NH}-\mathrm{TSC})_{2}\right] \mathrm{Cl}(3)(\mathrm{MH}-\mathrm{TSC}=(\mathrm{E})-2-(1$-(pyridin-2-yl)ethylidene)hydrazinecarbothioamide, $\mathrm{ME}-\mathrm{TSC}=$ (E)-N-ethyl-2-(1-(pyridin-2-yl)ethylidene) hydrazinecarbothioamide, NH-TSC = (Z)-2-(amino(pyridin2-yl)methylene)hydrazinecarbothioamide) were synthesized and structurally characterized. X-ray analyses revealed that 1 and 2 possessed similar a neutral mononuclear unit in which one tridentate TSC ligand and one leaving group $\left(\mathrm{Cl}^{-}\right)$coordinated to Pt(II) ion, while 3 was cationic and formed by two NH-TSC ligands surrounding one $\mathrm{Pt}$ atom in a meridional arrangement. UV-visible and fluorescence spectra of human serum albumin (HSA) with the complexes displayed that the quenching mechanism of HSA by 1-3 might be a static binding mode. Moreover, synchronous fluorescence experiments proved that 1-3 affected the microenvironment of tryptophan residues of HSA. In addition, the antiproliferative activities against MCF-7 (human breast cancer lines), HepG-2 (human liver hepatocellular carcinoma cell line), $\mathrm{NCl}-\mathrm{H} 460$ (non-small cell lung cancer lines) and HeLa (human epithelial cervical cancer cell line) were screened for 1-3. Inspiringly, their cytotoxic activity $\left(I C_{50}=1.7-9.6 \mu \mathrm{M}\right)$ appeared much better than that of cisplatin $\left(I C_{50}=5.2-13.5 \mu \mathrm{M}\right)$ against different cell lines, respectively. Among them, complex 3 exhibited the strongest inhibition on the viability of all tested cell lines with IC $C_{50}$ values of 1.7-2.2 $\mu \mathrm{M}$. Inductively-coupled plasma mass spectrometry (ICPMS) showed that 3 accumulated rapidly in cells and reached intracellular levels of up to 10 -fold higher than those determined for 1 and 2. Furthermore, fluorescence microscopic observation and flow cytometric analysis revealed that 1-3 could effectively induce apoptosis of HeLa cells, which were arrested in the S phase after treatment with 1 (30.31\%) and 3 (46.96\%), and in G2 phase with 2 (20.2\%). All the results mentioned above suggest that complexes 1-3 might be efficient antitumor agents.

\section{Introduction}

Cisplatin (cis-diamminedichloroplatinum(II)), capable of efficiently binding to and damaging DNA, ${ }^{1}$ has been widely used in the clinical treatment of various cancers since 1978. It functions in particular with respect to the therapy of head and neck, testicular, small lung cell and ovarian cancers..$^{2-5}$ Unfortunately,

\footnotetext{
aDepartment of Chemical Biology, Tianjin Key Laboratory on Technologies Enabling Development of Clinical Therapeutics and Diagnostics (Theranostics), School of Pharmacy, Tianjin Medical University, Tianjin 300070, P. R. China. E-mail: xujingyuan@tmu.edu.cn; Tel: +8602283336929

${ }^{b}$ Department of Sanitary Chemistry, School of Public Health, Tianjin Medical University, Tianjin 300070, P. R. China. E-mail: shenjun@tmu.edu.cn; Tel: +86022 83336638

$\dagger$ Electronic supplementary information (ESI) available: ${ }^{1} \mathrm{H}$ and ${ }^{13} \mathrm{C}$ NMR of ligand, corresponding figures of 1 and 2. CCDC 1471505-1471507 for 1-3. For ESI and crystallographic data in CIF or other electronic format see DOI: $10.1039 / \mathrm{c} 7 \mathrm{ra04443g}$

$\ddagger$ These authors contributed equally to this work.
}

cisplatin exhibits some drawbacks including severe side effects, ${ }^{6}$ acquired drug resistance ${ }^{7}$ and low water-solubility, ${ }^{8}$ which seriously limit its clinical applications. To combat those limitations, researchers have been exploring new Ptcompounds to improve antitumor efficiency.

Optimizing ligand structure is a usual strategy to design and construct new platinum antitumor agents. Therefore, a large number of so-called non-classical platinum complexes, which are structurally different from classical Pt drugs, have recently attracted researchers' attention. ${ }^{9}$ These complexes usually have monofunctional, cationic or high-valence Pt(Iv) features, which might lead to a distinctly different manner of antitumor activity compared to current cisplatin-like drugs. ${ }^{10}$

Thiosemicarbazone (TSC) includes thousands of compounds, and many of them may possess various biological activities. It was reported that 2-formylpyridine TSC could have anti-leukemic activity in mice. ${ }^{11}$ Additionally, 3-AP (3aminopyridine-2-carboxaldehyde thiosemicarbazone) is an inhibitor of ribonucleotide reductase (RNR) that catalyzes the 
reductive conversion of RNA building blocks into DNA building blocks for DNA replication and repair. ${ }^{\mathbf{1 2 , 1 3}}$ So, 3-AP exhibites efficient antitumor activities and have undergone phase II clinical trials. Meanwhile, combination of 3-AP and cisplatin could enhance the clinical efficacy. ${ }^{\mathbf{1 4 , 1 5}}$ Moreover, Dp44mT is a terminally dimethylated derivative of 3-AP, and it was shown to be 100-fold more potent than 3-AP with respect to cytotoxicity to tumor cells. ${ }^{16}$ Not only as antitumor agents, but also TSC could be applied in molecular imaging, metal-sensing, antiviral, anti-microbial, and anti-inflammatory. ${ }^{17-19}$

Previously, our group synthesized a tetranuclear TSCbased Pt(II) complex in the laboratory. ${ }^{20}$ It showed intense nuclease activity that could degrade DNA completely. However, this complex was little cytotoxic to tumor cells, probably because of its low solubility and difficulty in the uptake by cells. In this work, we designed and synthesized three mononuclear complexes 1-3 based on ligands MH-TSC, ME-TSC, and NH-TSC, respectively, attempting to improve solubility and cytotoxicity, and explore the structure-activity relationship. The HSA-binding, cytotoxicity, and apoptotic induction and celluar uptake of the complexes were investigated.

\section{Experimental}

\section{Materials and physical measurements}

All chemicals were purchased from commercial sources and used without further purification. Tris-HCl buffer solution was prepared using triple-distilled water. Reactions were typically carried out in air, all chemical solvents were dried and distilled by standard methods before use (cautious: $\mathrm{MeOH}$ must dry over $\mathrm{Mg}$ and $\mathrm{I}_{2}$ ). IR spectra were recorded on a Nicolet 380 spectrometer as $\mathrm{KBr}$ pellets in the range $4000-375 \mathrm{~cm}^{-1}$ with the OMNIC software. NMR measurements were recorded on a Bruker AVANCE III 400 spectrometer with tetramethylsilane as the internal standard. Electrospray ionization mass spectrometry (ESI-MS) was analyzed using an Agilent MS instrument with an ion spray source using electrospray ionization in positive-ion mode. Single crystal data were collected on a Rigaku Saturn X-ray CCD diffractometer using MoK $\alpha$ radiation. UV spectra were measured using a JASCO V-770 spectrophotometer. Fluorescence spectral data were obtained using a Shimadzu RF-5301 fluorescence spectrophotometer at the approved temperature. 3-(4,5-Dimethyl-2-thiazolyl)-2,5diphenyl-2-H-tetrazolium bromide (MTT), Crystal Violet, Hoechst 33342, Propidium Iodide (PI), and HSA were purchased from Sigma-Aldrich Corporation. DMEM was obtained from Gbico and Fetal Bovine Serum (FBS) was from Hyclone. Annexin V-FITC/PI Apoptosis Detection Kit was purchased from MBL. Human cervical cancer cell lines (HeLa), human breast cancer lines (MCF-7), human hepatoma cell lines (HepG-2) and non-small cell lung cancer lines (NCI-H460) were obtained from American Type Culture Collection (Rockville, MD, USA). All the cells were cultured with DMEM which contained $10 \% \mathrm{FBS}, 100 \mu \mathrm{g} \mathrm{mL}^{-1}$ penicillin and $100 \mu \mathrm{g} \mathrm{mL}$ streptomycin in a humidified atmosphere including $5 \% \mathrm{CO}_{2}$ at $37^{\circ} \mathrm{C}$.

\section{Synthesis of MH-TSC and ME-TSC}

The synthetic route of all ligands are based on literatures reported previously: ${ }^{21-23}$ 2-acetylpyridine $(6.65 \mathrm{~g}, 0.054 \mathrm{~mol})$ was dissolved in a solution of sodium in $\mathrm{MeOH}$ which had been dried over $\mathrm{CaSO}_{4}$ under stirring for $0.5 \mathrm{~h}$. The thiosemicarbazide (5 g, $0.054 \mathrm{~mol}$ ) or N(4)-ethylthiosemicarbazide $(6.43 \mathrm{~g}, 0.054 \mathrm{~mol})$ was added in small portions to the above solution, then the mixture was refluxed for another $4 \mathrm{~h}$. The solution was cooled to room temperature and filtered, after that, the yellowish residue was dissolved and recrystallized from methanol. MH-TSC: yield: $9.26 \mathrm{~g}$ (ca. 79.5\%). IR, ${ }^{1} \mathrm{H}$ and ${ }^{13} \mathrm{C}$ NMR analysis data of MH-TSC were listed in ESI. $\dagger^{1} \mathrm{H}$ NMR (DMSO-d 6 , $\delta / \mathrm{ppm}): 10.30(\mathrm{~s}, 1 \mathrm{H}), 8.57$ (d, 1H), 8.41 (d, 2H), 8.17$8.06(\mathrm{~m}, 1 \mathrm{H}), 7.78(\mathrm{td}, 1.5 \mathrm{~Hz}, 1 \mathrm{H}), 7.37(\mathrm{dd}, 1 \mathrm{H}), 2.38(\mathrm{~s}, 3 \mathrm{H}) .{ }^{13} \mathrm{C}$ NMR (DMSO-d $\left.{ }_{6}, \delta / \mathrm{ppm}\right): 179.07$ (s), 154.62 (s), 148.37 (s), 148.21 (s), 136.34 (s), 123.90 (s), 120.84 (s), 12.08 (s). ME-TSC: yield: $10.73 \mathrm{~g}$ (ca. 82\%). ${ }^{1} \mathrm{H}$ NMR (DMSO-d ${ }_{6}, \delta / \mathrm{ppm}$ ): 10.27 (s, $\left.1 \mathrm{H}\right), 8.70$ (t, 1H), 8.59 (ddd, 1H), 8.42 (d, 1H), 7.83 (tt, 1H), 7.40 (ddd, 1H), $3.64(\mathrm{~m}, 2 \mathrm{H}), 2.40(\mathrm{~s}, 3 \mathrm{H}), 1.17$ (t, 3H). ${ }^{13} \mathrm{C}$ NMR (DMSO-d6, $\delta /$ ppm): 177.60 (s), 154.68 (s), 148.43 (s), 147.91 (s), 136.28 (s), 123.85 (s), 120.75 (s), 38.51 (s), 14.43 (s), 12.09 (s).

\section{Synthesis of NH-TSC}

This compound was synthesized in a similar way to that of $\mathrm{MH}$ TSC, using 2-cyanopyridine $(5.63 \mathrm{~g}, 0.054 \mathrm{~mol})$ instead of 2acetylpyridine (6.65 g, $0.054 \mathrm{~mol})$. Yield: $6.38 \mathrm{~g}$ (ca. $60 \%) .{ }^{1} \mathrm{H}$ NMR (d d $_{6}$ DMSO, $\left.\delta / \mathrm{ppm}\right): 10.06(\mathrm{~s}, 1 \mathrm{H}), 8.55(\mathrm{~d}, 1 \mathrm{H}), 8.44(\mathrm{~d}, 1 \mathrm{H})$, $7.95(\mathrm{~s}, 1 \mathrm{H}), 7.86-7.75(\mathrm{~m}, 2 \mathrm{H}), 7.43(\mathrm{dd}, 1 \mathrm{H}), 6.92(\mathrm{~s}, 2 \mathrm{H}) .{ }^{13} \mathrm{C}$ NMR (d d $\left.^{-D M S O}, \delta / \mathrm{ppm}\right): 176.64$ (s), 150.15 (s), 147.85 (s), 141.86-140.20 (m), 136.64 (s), 124.48 (s), 121.10 (s).

\section{Synthesis of complexes}

Synthesis of [Pt(MH-TSC)Cl] (1). A solution of $\mathrm{K}_{2} \mathrm{PtCl}_{4}$ $(0.083 \mathrm{~g}, 0.2 \mathrm{mmol})$ in $\mathrm{H}_{2} \mathrm{O}(18 \mathrm{~mL})$ was added into a white solution of MH-TSC (0.039 g, $0.2 \mathrm{mmol})$ in $\mathrm{MeOH}(12 \mathrm{~mL})$ under stirring for $3 \mathrm{~h}$. The yellow reaction mixture was filtered and left to stand at room temperature for slow evaporation, and the bolarious crystals suitable for X-ray analysis were collected after several days. Yield: $50 \mathrm{mg}$ ( $c a .41 \%$ based on Pt). Elemental analysis (\%): calc. for 1: C, 22.65; H, 2.12; N, 13.21. Found: C, 22.64; H, 2.10; N, 13.27. Selected IR data $\left(\mathrm{KBr}, \mathrm{cm}^{-1}\right): 3423(\mathrm{~m})$, 3322 (s), 3184.1 (w), 1600.1 (s), 1500.2 (s), 1455 (vs), 1349.7 (w), $1313.2(\mathrm{w}), 1173.2(\mathrm{~m}), 1126.6(\mathrm{w}), 1007.4(\mathrm{w}), 766.6(\mathrm{~m}), 723.5$ (w).

Synthesis of [Pt(ME-TSC)Cl] (2). Complex 2 was prepared according to the similar procedure of 1, using ME-TSC $(0.044 \mathrm{~g}$, $0.2 \mathrm{mmol})$ instead of MH-TSC $(0.039 \mathrm{~g}, 0.2 \mathrm{mmol})$ to the reaction mixture. Yield: $51 \mathrm{mg}$ ( $c a .40 \%$ based on Pt). Elemental analysis (\%): calc. for 2: C, 26.56; H, 2.88; N, 12.39. Found: C, 26.64; H, 2.85; N, 12.23. Selected IR data $\left(\mathrm{KBr}, \mathrm{cm}^{-1}\right): 3343.9(\mathrm{~s})$, 2973 (w), 1556.6 (w), 1513 (s), 1455.1 (s), $1373.9(\mathrm{w}), 1328.7(\mathrm{w})$, $1170.5(\mathrm{~m}), 1051(\mathrm{w}), 767.4(\mathrm{~m})$.

Synthesis of [Pt(NH-TSC)2]Cl (3). Complex 3 was prepared according to the similar procedure of 1 , using NH-TSC $(0.039 \mathrm{~g}$, $0.2 \mathrm{mmol})$ instead of MH-TSC $(0.039 \mathrm{~g}, 0.2 \mathrm{mmol})$ to the 
reaction mixture. Yield: $85 \mathrm{mg}$ ( $c a .53 \%$ based on Pt). Elemental analysis (\%): calc. for 3: C, 26.33; H, 2.98; N, 21.94. Found: C, 26.40; H, 2.94; N, 21.98. Selected IR data $\left(\mathrm{KBr}, \mathrm{cm}^{-1}\right): 3380(\mathrm{~m})$, $3272.6(\mathrm{~m}), 3165(\mathrm{~m}), 2968(\mathrm{w}), 1647.7(\mathrm{~s}), 1605.6(\mathrm{~m})$, $1550.9(\mathrm{~m}), 1473$ (s), $1413.9(\mathrm{w}), 1287.5(\mathrm{w}), 1185.4(\mathrm{w}), 1053(\mathrm{w})$, $740.4(\mathrm{w})$.

\section{X-ray crystallographic studies}

Crystals were picked up with a glass fiber and immediately mounted in a cold nitrogen stream to prevent loss of solvent. Intensity data were collected by a Rigaku Saturn CCD diffractometer using MoK $\alpha$ radiation $(\lambda=0.71073 \AA)$ with the $\omega-2 \theta$ scan technique at 113(2) K. An empirical absorption correction was applied to the raw intensities. The structures were solved by direct methods SHELXS-97 and refined with full matrix leastsquares technique on $F^{2}$ using SHELXL-97. ${ }^{24}$ The hydrogen atoms were added theoretically, riding on the concerned atoms, and refined with fixed thermal factors. Structures were checked for higher symmetry using PLATON. ${ }^{25}$ Further crystallographic data and experimental details for structural analyses of 1-3 are summarized in Table 1. Selected bond lengths ( $(\AA)$ and bond angles $\left(^{\circ}\right)$ of 1-3 are listed in Table 2. Crystallographic data for the structures reported in this article have been deposited at the Cambridge Crystallographic Data Centre, CCDC No. 14715051471507 for $1-3 . \dagger$

\section{HSA binding studies}

Fluorescence quenching and UV spectrophotometry were used to carry out the protein (HSA) binding experiments. The protein was prepared in the phosphate buffer solution (containing $0.01 \mathrm{M} \mathrm{NaH} \mathrm{PO}_{4}$ and $\mathrm{Na}_{2} \mathrm{HPO}_{4}$ in aqueous medium at $\mathrm{pH}=$
Table 2 Bond lengths $[\AA]$ and angles $\left[^{\circ}\right]$ for $1-3$

\begin{tabular}{|c|c|c|c|}
\hline \multicolumn{4}{|l|}{1} \\
\hline $\operatorname{Pt}(1)-\mathrm{N}(2)$ & $1.951(2)$ & $\mathrm{N}(2)-\mathrm{Pt}(1)-\mathrm{N}(1)$ & $80.77(9)$ \\
\hline $\operatorname{Pt}(1)-\mathrm{N}(1)$ & $2.041(2)$ & $\mathrm{N}(2)-\mathrm{Pt}(1)-\mathrm{S}(1)$ & $85.27(7)$ \\
\hline $\operatorname{Pt}(1)-S(1)$ & $2.2557(7)$ & $\mathrm{N}(1)-\mathrm{Pt}(1)-\mathrm{S}(1)$ & $166.02(7)$ \\
\hline $\operatorname{Pt}(1)-\mathrm{Cl}(1)$ & $2.3233(7)$ & $\mathrm{N}(2)-\mathrm{Pt}(1)-\mathrm{Cl}(1)$ & $178.59(7)$ \\
\hline $\mathrm{N}(1)-\mathrm{Pt}(1)-\mathrm{Cl}(1)$ & $98.25(6)$ & $\mathrm{S}(1)-\mathrm{Pt}(1)-\mathrm{Cl}(1)$ & $95.69(2)$ \\
\hline $\mathrm{C}(8)-\mathrm{S}(1)-\mathrm{Pt}(1)$ & $94.14(9)$ & $\mathrm{C}(6)-\mathrm{N}(2)-\operatorname{Pt}(1)$ & $117.8(2)$ \\
\hline \multicolumn{4}{|l|}{2} \\
\hline $\operatorname{Pt}(1)-\mathrm{N}(2)$ & $1.959(2)$ & $\mathrm{N}(2)-\mathrm{Pt}(1)-\mathrm{N}(1)$ & $80.79(10)$ \\
\hline $\operatorname{Pt}(1)-\mathrm{N}(1)$ & $2.039(2)$ & $\mathrm{N}(2)-\mathrm{Pt}(1)-\mathrm{S}(1)$ & $85.24(7)$ \\
\hline $\operatorname{Pt}(1)-S(1)$ & $2.2568(8)$ & $\mathrm{N}(1)-\mathrm{Pt}(1)-\mathrm{S}(1)$ & $165.98(7)$ \\
\hline $\operatorname{Pt}(1)-\mathrm{Cl}(1)$ & $2.3145(7)$ & $\mathrm{N}(2)-\mathrm{Pt}(1)-\mathrm{Cl}(1)$ & $177.77(7)$ \\
\hline $\mathrm{N}(1)-\mathrm{Pt}(1)-\mathrm{Cl}(1)$ & $97.17(7)$ & $\mathrm{C}(8)-\mathrm{S}(1)-\mathrm{Pt}(1)$ & $94.33(10)$ \\
\hline $\mathrm{S}(1)-\mathrm{Pt}(1)-\mathrm{Cl}(1)$ & $96.82(3)$ & $\mathrm{C}(1)-\mathrm{N}(1)-\mathrm{Pt}(1)$ & $129.0(2)$ \\
\hline \multicolumn{4}{|l|}{3} \\
\hline $\operatorname{Pt}(1)-\mathrm{N}(3)$ & $1.971(2)$ & $\mathrm{N}(3)-\mathrm{Pt}(1)-\mathrm{N}(1)$ & $80.43(10)$ \\
\hline $\operatorname{Pt}(1)-\mathrm{N}(1)$ & $2.059(2)$ & $\mathrm{N}(3)-\mathrm{Pt}(1)-\mathrm{S}(1)$ & $84.54(7)$ \\
\hline $\operatorname{Pt}(1)-S(1)$ & $2.2529(8)$ & $\mathrm{N}(3)-\operatorname{Pt}(1)-\mathrm{S}(2)$ & $173.39(7)$ \\
\hline $\operatorname{Pt}(1)-S(2)$ & $2.3049(8)$ & $\mathrm{N}(1)-\mathrm{Pt}(1)-\mathrm{S}(1)$ & $164.96(7)$ \\
\hline $\mathrm{N}(1)-\mathrm{Pt}(1)-\mathrm{S}(2)$ & $99.68(7)$ & $\mathrm{C}(7)-\mathrm{S}(1)-\mathrm{Pt}(1)$ & $94.86(10)$ \\
\hline$S(1)-P t(1)-S(2)$ & $95.31(3)$ & $\mathrm{C}(14)-\mathrm{S}(2)-\mathrm{Pt}(1)$ & $108.46(10)$ \\
\hline
\end{tabular}

7.2). HSA solution concentration was controlled at $5 \times 10^{-7} \mathrm{M}$ (based on the molecular weight of HSA $66 \mathrm{kD}$ ), and then the solution was kept in the dark at $277 \mathrm{~K}$ overnight. Fluorescence quenching measurements were performed by keeping the concentration of HSA constant while gradually increasing the concentration of 1-3 at $25^{\circ}$ (298 K), respectively. Fluorescence spectra were recorded at an excitation wavelength of $290 \mathrm{~nm}$ and emission wavelength range from 300 to $500 \mathrm{~nm}$. UV spectrometry was performed using a JASCO V-770

Table 1 Summary of crystal data for $1-3$

\begin{tabular}{|c|c|c|c|}
\hline Complex & 1 & 2 & 3 \\
\hline Empirical formula & $\mathrm{C}_{8} \mathrm{H}_{9} \mathrm{ClPtN}_{4} \mathrm{~S}$ & $\mathrm{C}_{10} \mathrm{H}_{13} \mathrm{ClPtN}_{4} \mathrm{~S}$ & $\mathrm{C}_{14} \mathrm{H}_{19} \mathrm{ClPtN}_{10} \mathrm{~S}_{2} \mathrm{O}$ \\
\hline Formula weight & 423.79 & 451.84 & 638.04 \\
\hline Temperature/K & $113(2)$ & $113(2)$ & $113(2)$ \\
\hline Wavelength/Å & 0.71073 & 0.71073 & 0.71073 \\
\hline Space group & $P 2_{1} / n$ & $C 2 / c$ & $P 1$ \\
\hline$a / \AA$ & $7.4429(7)$ & $15.957(3)$ & $8.101(2)$ \\
\hline$b / \AA$ & $13.5839(13)$ & $15.120(2)$ & $9.3191(19)$ \\
\hline$c / \AA$ & $10.5375(10)$ & $12.362(2)$ & $14.094(3)$ \\
\hline$\alpha /^{\circ}$ & 90 & 90 & $92.2270(10)$ \\
\hline$\beta /^{\circ}$ & $95.673(2)$ & $122.314(2)$ & $99.051(8)$ \\
\hline$\gamma / /^{\circ}$ & 90 & 90 & $104.437(8)$ \\
\hline Volume $/ \AA^{3}$ & $1060.16(17)$ & $2520.7(7)$ & $1014.2(4)$ \\
\hline$Z$ & 4 & 8 & 2 \\
\hline$\rho$ calcd $/ \mathrm{mg} \mathrm{m}^{-3}$ & 2.655 & 2.387 & 2.089 \\
\hline$F(000)$ & 784 & 1704 & 616 \\
\hline Crystal size/mm & $0.15 \times 0.12 \times 0.10$ & $0.20 \times 0.15 \times 0.12$ & $0.20 \times 0.18 \times 0.15$ \\
\hline$\theta$ limits $/^{\circ}$ & $3.00-27.50$ & $1.84-27.91$ & $3.22-27.52$ \\
\hline Reflections collected & 13436 & 15956 & 13023 \\
\hline Unique reflections & $2437[R($ int $)=0.0437]$ & $2885[R(\mathrm{int})=0.0276]$ & $4552[R(\mathrm{int})=0.0357]$ \\
\hline Data/restraints/parameters & $2437 / 0 / 136$ & $2885 / 3 / 166$ & $4552 / 0 / 278$ \\
\hline Goodness of fit on $F^{2}$ & 0.784 & 0.941 & 0.891 \\
\hline$R_{1}(I>2 \sigma(I))$ & $R_{1}=0.0161$ & $R_{1}=0.0159$ & $R_{1}=0.0202$ \\
\hline $\mathrm{w} R_{2}$ (all data) & $\mathrm{w} R_{2}=0.0384$ & $\mathrm{w} R_{2}=0.0326$ & $\mathrm{w} R_{2}=0.0504$ \\
\hline Largest diff. peak and hole/e $\AA^{3}$ & 1.049 and -1.295 & 0.561 and -0.899 & 1.827 and -1.282 \\
\hline
\end{tabular}


spectrophotometer equipped with a $2 \mathrm{~cm}$ quartz cell. Absorption titration experiments were done by keeping the concentration of HSA constant $\left(5 \times 10^{-6} \mathrm{M}\right)$ while adding the same concentration solution of 1-3, respectively. Synchronous fluorescence spectral experiments were operated with the same method as above while keeping the $D$ values $(\Delta \lambda)$ between excitation and emission wavelengths, which are stabilized at 15 and $60 \mathrm{~nm}$ respectively, at room temperature. All the data were obtained after each successive addition of HSA solution and equilibration (ca. $10 \mathrm{~min}$ ).

\section{Cytotoxicity evaluation}

MTT assay. MTT assay was used to evaluate the cell viability effect of 1-3 with cisplatin as control. In brief, HeLa, MCF-7, HepG-2 and NCI-H460 cells were plated in 96 well-plate with three replica wells and incubated at $37{ }^{\circ} \mathrm{C}$ and $5 \% \mathrm{CO}_{2}$ for $24 \mathrm{~h}$. The concentration was 3000 cells per well. After the cells attached to wells, three complexes and cisplatin with various concentration $(100,50,25,12.5,6.25,3.12,1.56,0.78,0.39 \mu \mathrm{M})$ were added and cultured for $48 \mathrm{~h}$. After this period of time, 20 $\mu \mathrm{L}$ MTT ( $5 \mathrm{mg} \mathrm{mL}^{-1}$ in PBS) was added to each well and cells were incubated at $37{ }^{\circ} \mathrm{C}$ for $4 \mathrm{~h}$. Finally, the medium was removed and $100 \mu \mathrm{L}$ DMSO was added to dissolve the formed formazan crystals. Cell viability were determined by reading absorbance at $570 \mathrm{~nm}$ using an Enzyme-linked Immunosorbent Assay (ELISA) reader.

Time curve assay of three agents on HeLa cell line. Time curve assay was still evaluated by MTT assay. HeLa cells were treated with 1-3 and cisplatin with ranging from 100 to $0.39 \mu \mathrm{M}$ for 12,24 and $48 \mathrm{~h}$, then incubated at $37{ }^{\circ} \mathrm{C}$. The detection method was similar to the mentioned above.

\section{Apoptosis evaluation}

Hoechst 33342 staining. We adopted Hoechst 33342 staining to assess the inducing apoptosis ability of 1-3. HeLa cells, with a density of $1 \times 10^{5}$ cells per well, were seeded in 6 well-plate and incubated for $24 \mathrm{~h}$ at $37{ }^{\circ} \mathrm{C}$. Then the cells were treated with fresh medium containing 10, 5, $2.5 \mu \mathrm{M}$ three agents respectively. After $48 \mathrm{~h}$, the cell was rinsed twice with $\mathrm{PBS}(\mathrm{pH}=$ 7.4) to remove excess amount of agents and then stained with Hoechst $33342\left(1 \mu \mathrm{g} \mathrm{mL}{ }^{-1}\right)$ for $15 \mathrm{~min}$ at room temperature. Finally, the cells were washed twice with $\mathrm{PBS}(\mathrm{pH}=7.4)$ to eliminate the surplus Hoechst 33342 interference and visualized with the aid of EPI fluorescence microscopy (Nikon eclipse E800).

Annexin V-FITC/PI double staining. For apoptosis quantitative analysis, $1 \times 10^{6}$ cells per well were plated in 6 well-plate and incubated at $37^{\circ} \mathrm{C}$ for $24 \mathrm{~h}$. Agents 1-3 at 2.5, 5, $10 \mu \mathrm{M}$ were added to each well, respectively. After incubated for $48 \mathrm{~h}$, cells were washed twice with PBS after the medium was removed and collected with trypsin (non-EDTA). Then the cells were centrifuged with $1200 \mathrm{rpm}$ for $10 \mathrm{~min}$ and rinsed once with PBS. After centrifugation, supernatant was removed and pellet was resuspended with $1 \times$ binding buffer. Annexin V-FITC (10 $\mu \mathrm{g} \mathrm{mL}^{-1}$ ) was added into the suspension and incubated for $15 \mathrm{~min}$ at room temperature and then stained with PI $(5 \mu \mathrm{g}$
$\mathrm{mL}^{-1}$ ) for $5 \mathrm{~min}$ at room temperature. The distribution of cell apoptosis was measured by a flow cytometer (BD FACS Calibur).

\section{Cell proliferation assay}

Cell cycle analysis. Cell cycle analysis was assessed by flow cytometry. Briefly, $1 \times 10^{6}$ cells were seeded in 6 well-plate and incubated for $24 \mathrm{~h}$. After attaching to well, the HeLa cells were treated with 1-3 at $2.5,5,10 \mu \mathrm{M}$ for $48 \mathrm{~h}$. At the end of the culture period, the cells were rinsed twice with cold $\mathrm{PBS}(\mathrm{pH}=$ 7.4), harvested with trypsin (containing EDTA) and centrifuged with $2000 \mathrm{rpm} 10 \mathrm{~min}$, then removed the supernatant and resuspended the pellets with $500 \mu \mathrm{L} 70 \%$ cold ethanol at $-20{ }^{\circ} \mathrm{C}$ over $48 \mathrm{~h}$. After being centrifuged to remove the ethanol and washing once with cold $\mathrm{PBS}(\mathrm{pH}=7.4)$, the cells were digested with RNase A $\left(100 \mu \mathrm{g} \mathrm{mL}{ }^{-1}\right)$ for $30 \mathrm{~min}$ at $37^{\circ} \mathrm{C}$ to avoid RNA interference and stained with PI $\left(50 \mu \mathrm{g} \mathrm{mL}{ }^{-1}\right)$ for $30 \mathrm{~min}$ at room temperature. Cell cycle distribution was analyzed immediately using a flow cytometer (BD FACS Calibur). The data was acquired and analyzed by ModFit 3.1 software.

\section{Monoclonal formation assay}

Cellular proliferation, an ability of cancer cells maintaining clonogenic capacity, was assessed by monoclonal formation assay. HeLa cells were plated with a density of 300 in 6 well-plate and incubated for 3 days until the cells attached to wells, complex 3 was added to the cells with various amounts $(0,2.5,5$, $10 \mu \mathrm{M}$ ) for $48 \mathrm{~h}$, and then the medium containing 3 was changed with fresh medium and continuously incubated for two weeks. After this period of time, cells were washed twice with PBS ( $\mathrm{pH}=7.4)$ and fixed with methanol-acetic acid $(3: 1)$ solution for $15 \mathrm{~min}$, stained with crystal violet solution $(1 \%$ crystal violet, $20 \%$ ethanol) for $30 \mathrm{~min}$, washed with PBS and examined with an inverted fluorescence microscope.

\section{Platinum uptake assay}

To assess the absorption capability of tumor cells to the three complexes, we examined the intracellular platinum content. ${ }^{26}$ In brief, cells $\left(1 \times 10^{6}\right.$ per well $)$ were placed in 6 -well plates and incubated for $24 \mathrm{~h}$. Then, cells were treated with complexes (4 $\mu \mathrm{M})$ at $37^{\circ} \mathrm{C}$ for 3,6 and $9 \mathrm{~h}$, respectively. After treatment, the cells were washed three times with PBS, digested with trypsinization, collected with cold PBS and centrifuged at $1500 \mathrm{rpm}$ for $5 \mathrm{~min}$. Finally, supernatant was discarded and samples were lyophilized using a freeze dry system.

Prior to analysis, the lyophilized samples were digested with $0.2 \mathrm{~mL}$ highpurity nitric acid at room temperature for $4 \mathrm{~h}$, diluted with $2 \mathrm{~mL}$ deionized water, centrifuged at $5000 \mathrm{rpm}$ for $15 \mathrm{~min}$, and transferred with an aliquot $0.2 \mathrm{~mL}$ to an ICP-MS autosampler tube for determining the Pt content. Thermo iCAP Q ICP-MS was calibrated with a Pt-containing acid matrix. The platinum content under each time point was expressed as ng Pt per million cells. 


\section{Results and discussion}

\section{$\mathrm{X}$-ray structure characterization}

Complexes 1-3 have been structurally characterized by single crystal X-ray analysis. A labelled plot of 1-3 is shown in Fig. 1. Complex 1 crystallizes in the monoclinic system with space group $P 2_{1} / n$ and consists of neutral asymmetric mononuclear platinum(II) units without crystallization water. The structure of 1 consists of neutral asymmetric mononuclear unit, in which $\mathrm{Pt}(\mathrm{II})$ ion is tetracoordinated. The basal plane is formed by imine nitrogen $\mathrm{N}(1)[\operatorname{Pt}(1)-\mathrm{N}(1)=2.041(2) \AA], \mathrm{N}(2)[\operatorname{Pt}(1)-\mathrm{N}(2)=$ 1.951(2) ̊], thione $\mathrm{S}(1)[\mathrm{Pt}(1)-\mathrm{S}(1)=2.2557(7) \AA]$ from MH-TSC ligand and one chlorine $\mathrm{Cl}(1)[\operatorname{Pt}(1)-\mathrm{Cl}(1)=2.3233(7) \AA]$. The donor atoms, $\mathrm{N}(1), \mathrm{N}(2), \mathrm{S}(1)$ and $\mathrm{Cl}(1)$, show a relatively good planarity, and $\operatorname{Pt}(1)$ displaced out of the basic plane towards the apex by $0.0151 \AA$. For 2 , it crystallizes in monoclinic $C 2 / c$ space group and presents a quite similar mononuclear Pt(II) structure to 1 owing to its slight ligand modification with ethyl instead of hydrogen in 1. As Fig. 1 shown, central Pt(II) ion in 2 is tetracoordinated, showing a good square planar geometry, surrounded by imine nitrogen $\mathrm{N}(1), \mathrm{N}(2)$ and carboxylate thione $\mathrm{S}(1)$ from ME-TSC ligand and one chlorine $\mathrm{Cl}(1)$. Complex 3 crystallizes in the triclinic crystal system with $P 1$ space group and consists of one $\left[\mathrm{Pt}(\mathrm{NH}-\mathrm{TSC})_{2}\right]^{+}$cation, one non-coordinating chloride anion, and one water solvent molecule. Each Pt centre is coordinated with two NH-TSC ligands, by virtue of two nitrogen and one sulfur atoms from one ligand $[\mathrm{Pt}(1)-\mathrm{N}(1)$ 2.059(2), Pt(1)-N(3) 1.971(2) and Pt(1)-S(1) 2.2529(8) §] , as well as one $\mathrm{S}$ atom from the other ligand $[\mathrm{Pt}(1)-\mathrm{S}(2) 2.3049(8) \AA]$ to build the square-planar coordination geometry. The bond distance $\operatorname{Pt}(1)-S(1)[2.2529(8) \AA]$ is shorter than $\operatorname{Pt}(1)-S(2)$ [2.3049(8) $\AA$ ]. Therefore, the two ligands do not display a similar coordinating pattern as common cases. The thiosemicarbazone moieties, C6N3-N4-C7-S1 and C13-N8-N9-C14-S2 have mean plane deviations of $0.020(6)$ and $0.018(6) \AA$, respectively, and are at an angle to each other of $74.3^{\circ}$. Meanwhile, no interesting hydrogen bond and $\pi-\pi$ stacking were found in these three complexes.

\section{HSA binding experiments}

Fluorescence spectroscopy of HSA. Qualitative analysis of binding of metal compounds to HSA was achieved by examining fluorescence spectra. The emission spectra of HSA in the presence of 1-3 were recorded in the wavelength range $300-500 \mathrm{~nm}$ by exciting the protein at $290 \mathrm{~nm}$. A remarkable fluorescence decrease of HSA was observed with increasing concentration of 1-3, which indicated that complexes can bind to the proteins effectively. Generally, fluorescence quenching can be described by the following Stern-Volmer eqn (1). ${ }^{27}$

$$
F_{0} / F=1+K_{\mathrm{q}} t_{0}[\mathrm{Q}]=1+K_{\mathrm{sv}}[\mathrm{Q}]
$$

In this equation, $F_{0}$ and $F$ represent the fluorescence intensities in the absence and presence of the quencher, respectively. $K_{\mathrm{q}}$ is the biomolecular quenching rate constant, $K_{\mathrm{sv}}$ is the quenching constant, $t_{0}$ is the average life-time of the biomolecule without the quencher $\left(t_{0}=6.2 \mathrm{~ns}\right)$ and [Q] is the concentration of quencher. The effect of complex 3 on HSA fluorescence intensity with Stern-Volmer plots are shown in Fig. 2. The corresponding Stern-Volmer quenching rate constant $K_{\mathrm{q}}$ of $1-3$ were $4.25 \times 10^{13}, 7.09 \times 10^{13}$ and $10.64 \times$ $10^{13} \mathrm{~L} \mathrm{~mol}^{-1} \mathrm{~s}^{-1}$, respectively. The results showed that quenching constant $K_{\mathrm{q}}$ for 1-3 was on the order of $10^{13} \mathrm{~L} \mathrm{~mol}^{-1}$ $\mathrm{s}^{-1}$, which was 1000 -fold higher than the maximum value possible for diffusion controlled quenching (i.e. $2.0 \times 10^{10} \mathrm{~L}$ $\left.\mathrm{mol}^{-1} \mathrm{~S}^{-1}\right) .{ }^{28}$ This revealed that the quenching was not caused by dynamic collision but by a static one. The quenching mechanism should be further explored by UV-vis absorption spectrometry.

In a dynamic quenching mechanism, with the addition of a quencher, the absorption spectrum of the fluorescent

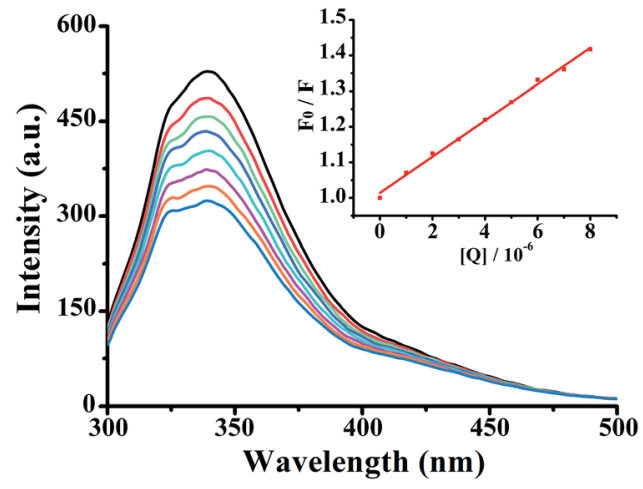

Fig. 2 Fluorescence spectra of HSA in the different concentrations of 3 at room temperature, $[\mathrm{HSA}]=5 \times 10^{-7} \mathrm{M}$, complex $3(0-8 \mu \mathrm{M})$. Inset: plot of $F_{0} / F v s$. [complex].

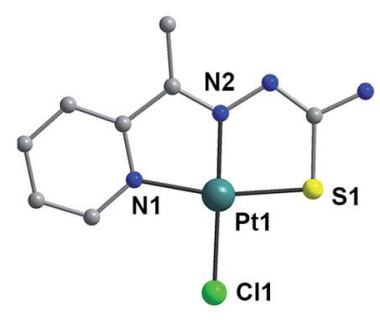

1

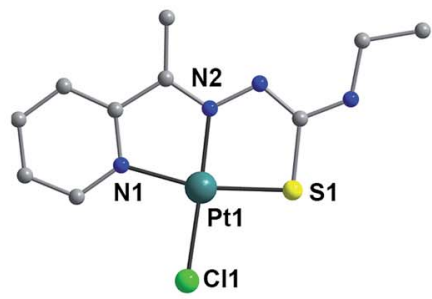

2

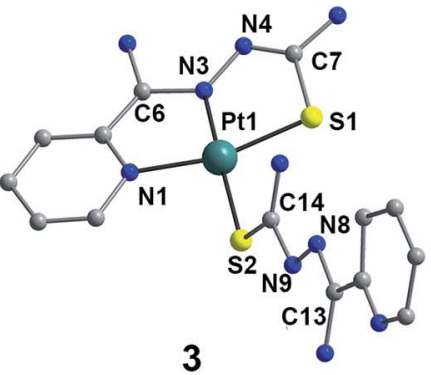

3

Fig. 1 DIAMOND views of 1-3 with the selected atom labeling scheme (hydrogen atoms omitted for clarity). 
substance is not changed, which due to the excited states of the fluorophore is not affected. While, the absorption spectrum will change in a static quenching, because new compound is formed between the quencher and HSA. The influences of the absorbance of HSA were observed by adding the same concentration of 1-3. From Fig. 3, the fluorescence of HSA caused by tryptophan, tyrosine, and phenylalanine residues exists. ${ }^{29}$ For $1-3$, the absorption spectra decreased in the presence of the complex, indicating that the microenvironment of the three aromatic acid residues was changed, and this can prove that 1-3 formed a novel complex with HSA. These data suggested that the $\mathrm{Pt}$ (II) complex could interact with HSA through a static quenching mode.

Synchronous fluorescence spectroscopy studies. It is reported that synchronous fluorescence spectroscopy is frequently used to characterize the interaction between the fluorescent probe and proteins, ${ }^{30}$ because it is of great importance for providing information about the molecular environment around the fluorophore molecules. ${ }^{31}$ The synchronous fluorescence spectroscopy performs the simultaneous scanning of excitation and emission spectra on a fluorimeter, and fixes the wavelength difference $(\Delta \lambda)$ between them. When $\Delta \lambda$ is stabilized at $15 \mathrm{~nm}$, the synchronous fluorescence represents the state of tyrosine residues, whereas $\Delta \lambda$ of $60 \mathrm{~nm}$ indicates that of tryptophan residues. ${ }^{32}$ The change of maximum emission wavelengths of tryptophan and tyrosine residues are related to the environmental change of their surroundings. From Fig. 4, it can be seen that upon addition of 1, the maximum emission wavelength showed no shift when $\Delta \lambda$ was equal to $15 \mathrm{~nm}$. However, the maximum emission wavelength displayed obviously red shift when $\Delta \lambda$ was equal to $60 \mathrm{~nm}$. The red shift indicated that the environment around HSA had changed with the transformation of conformation. ${ }^{33}$ Complexes $\mathbf{2}$ and $\mathbf{3}$ displayed similar manner to $\mathbf{1}$ (data were shown in ESI $\dagger$ ).

MTT assay. MTT, the soluble yellow tetrazolium salt, is induced to purple formazan crystals by succinate dehydrogenase in the mitochondria of viable cell, ${ }^{34}$ while dead cells are dysfunction. Therefore, we adopted MTT assay to evaluate the

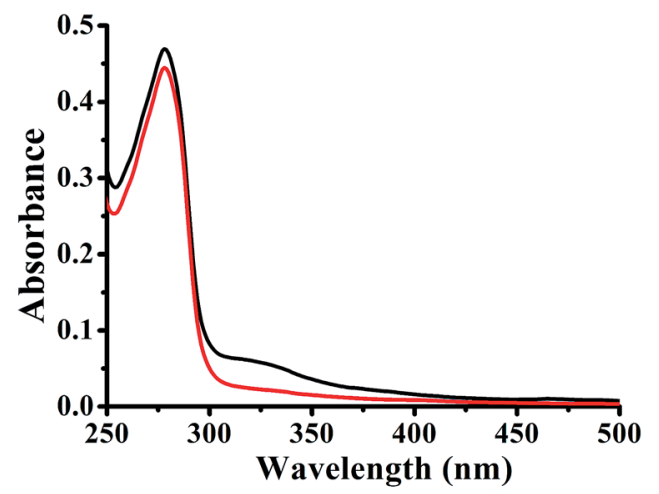

Fig. 3 UV-vis absorption spectra of HSA in the absence and presence of 3. Black line: the absorption spectrum of HSA. Red line: the absorption spectrum of HSA in the presence of 3 at the same concentration, $[\mathrm{HSA}]=[$ complex $]=5 \times 10^{-6} \mathrm{M}$.
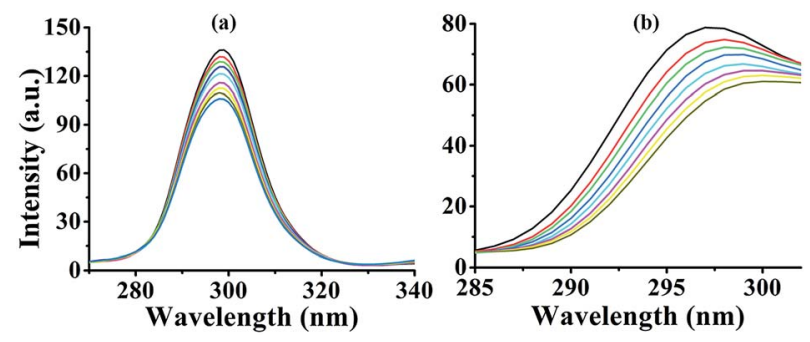

Fig. 4 Synchronous fluorescence spectra of HSA at room temperature upon addition of $3, \Delta \lambda=15 \mathrm{~nm}(\mathrm{a}) ; \Delta \lambda=60 \mathrm{~nm}$ (b). Concentrations of complex is $0.0-8.0 \mu \mathrm{M}$.

cell viability of three complexes against HeLa, MCF-7, HepG-2 and NCI-H460 cells with cisplatin as control. The results were summarized in Table 3, complexes 1-3 and cisplatin all displayed antitumor effect against four cancer cells. The $\mathrm{IC}_{50}$ values of cisplatin ranged of 5.2-13.5 $\mu \mathrm{M}$ in accordance with the literature reported. ${ }^{35}$ Encouragingly, three complexes with $\mathrm{IC}_{50}$ values ranging of 1.7-9.6 $\mu \mathrm{M}$ showed obviously increased antitumor activity against human cancer cells, compared with cisplatin. Moreover, the antiproliferative activity of $\mathbf{3}$ was higher 7.9 and 6.2 times than cisplatin against MCF-7 and HeLa cells. Given that complex 3 is cation, it may take advantage of its cationic feature to pass through cells membrane easily.

As three complexes exhibited strong antitumor effect, we determined to investigate the action manner of them by MTT assay. As shown in Fig. 5, complexes 1 and 3 exerted antitumor activity in a dose- and time-dependent behavior except 2 . Along with the increasing concentration and time, the antitumor effect of 1-3 were strikingly enhanced. We did not expect that antitumor effect of $\mathbf{1}$ and $\mathbf{3}$ gradually reduced with the time extending while 2 exerted antiproliferation activity in a rapid manner. For example, when the HeLa cells were treated with 2 for $24 \mathrm{~h}$, the $\mathrm{IC}_{50}$ values was lower 2 times than that of $\mathbf{1}$ and $\mathbf{3}$ with the same processing time. When the cells were incubated with 2 for $48 \mathrm{~h}$, the $\mathrm{IC}_{50}$ values remained unchanged while that of 1 and 3 decreased two times than that of 2 .

\section{Apoptosis evaluation}

Hoechst 33342 staining. Hoechst 33342 dye could penetrate plasma membrane and selectively combine with DNA. ${ }^{36}$ The permeability of the apoptotic cells membrane were elaborated compared with normal membrane and more dyes gathered in

Table 3 The $I C_{50}$ values of three complexes in comparison with cisplatin against four cancer cell

\begin{tabular}{|c|c|c|c|c|}
\hline \multirow[b]{2}{*}{ Cell } & \multicolumn{4}{|c|}{$\left.\underline{\text { Complex IC }_{50}(\mu \mathrm{mol} \mathrm{L}}{ }^{-1}\right)$} \\
\hline & 1 & 2 & 3 & Cisplatin \\
\hline MCF-7 & $6.6 \pm 2.1$ & $8.3 \pm 3.3$ & $1.7 \pm 0.4$ & $13.5 \pm 4.3$ \\
\hline HepG-2 & $4.8 \pm 1.6$ & $7.2 \pm 1.9$ & $2.6 \pm 0.6$ & $9.71 \pm 2.7$ \\
\hline NCI-H460 & $9.6 \pm 3.1$ & $6.6 \pm 2.0$ & $2.8 \pm 1.1$ & $5.2 \pm 2.2$ \\
\hline HeLa & $7.4 \pm 3.5$ & $6.4 \pm 2.4$ & $2.2 \pm 0.8$ & $13.6 \pm 4.6$ \\
\hline
\end{tabular}



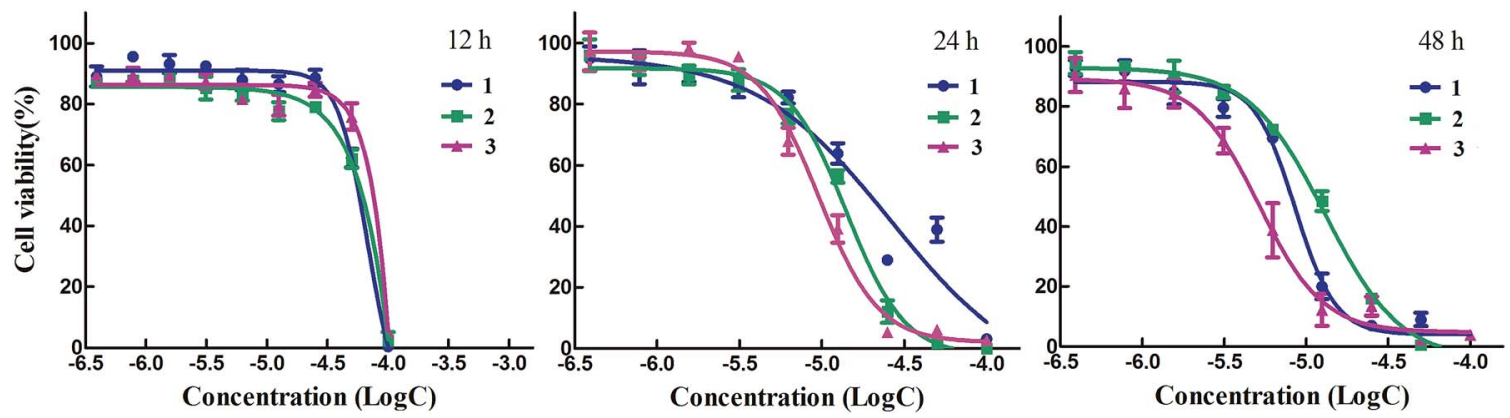

Fig. 5 The cell viability change of HeLa cells after complexes 1-3 treatment for 12, 24 and 48 h.

nucleus. Meanwhile, obvious blue fluorescence could be observed in nucleus area. Therefore, we used this difference to distinguish the apoptotic cells and normal cells. HeLa cells were treated with 1-3 for $48 \mathrm{~h}$ and stained with Hoechst 33342, the results were shown in Fig. 6 . As the concentration of complexes was increased, the intensity of bright vision was enhanced simultaneously, which indicated that 1-3 exactly caused cell apoptosis in HeLa cells.

Annexin V-FITC/PI double staining. To quantitative analysis of the percentage of apoptosis, we adopted Annexin V-FITC/PI double staining to assess the apoptosis inducing ability. Briefly, the HeLa cells were stained by single Annexin V-FITC or single PI illustrating that the cancer cells occurred early apoptosis or necrosis. Annexin V-FITC/PI staining data was shown in Fig. 7, when concentration of 1-3 was elevated, the percentage of apoptosis was correspondingly enhanced especially for 3 . The apoptosis inducing levels of three complexes were almost the same at $5 \mu \mathrm{M}(19 \%$ for $1,13 \%$ for 2 and $13 \%$ for 3). However, when the concentration was added to $10 \mu \mathrm{M}$, the inducing behavior of $3(35 \%)$ was significantly stronger than that of $1(19 \%)$ and 2 (25\%). This result suggested that 1-3 exerted antitumor activities by inducing cell apoptosis and 3 would be the most promising antitumor agent.

Cell cycle analysis. Cell cycle arrest played an important role in the development of anticancer agent. As three complexes were more efficient than cisplatin in terms of inducing apoptosis, we speculated that they may have influence on the cell cycle arrest. HeLa cells were treated with 1-3 and fixed for flow cytometry analysis. As shown in Fig. 8, all complexes exactly interfered cell cycle distribution and the effect displayed a concentration-dependent manner. Complex 2 could delay or inhibit cell cycle progression by arresting at G2 phase, while 1 and 3 induce cell cycle arrest at G2/M at low concentration. At
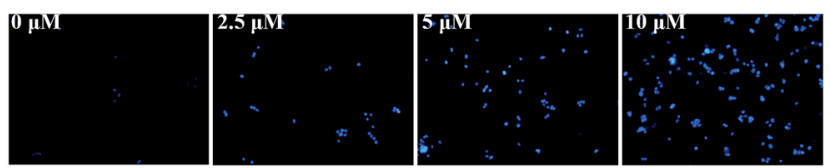

Fig. 6 Hoechst 33342 staining detected apoptosis in HeLa cells after treatment by 3 for $48 \mathrm{~h}$ at the concentrations of $0,2.5,5$, and $10 \mu \mathrm{M}$. As concentration increased, the intensity of bright vision gradually enhanced. high concentration, the complexes $\mathbf{1}$ and $\mathbf{3}$ induce cell cycle arrest at $\mathrm{S}$ phase, especially for $\mathbf{3}$. For example, compared with control group (25.4\% in S phase, $10.44 \%$ in G2 phase), after the cells were treated with $10 \mu \mathrm{M}$ complexes for $48 \mathrm{~h}, 46.96 \%$ of the cells treated with 3 and $30.31 \%$ of that treated with 1 were arrested in S phase, while $20.2 \%$ of the cells treated with 2 were stopped in G2 phase. Additionally, the monoclonal formation assay also confirmed that $\mathbf{3}$ had a major pact on cell proliferation (ESI $\dagger$ ). These results demonstrated that three complexes would be the potential candidates for antitumor agents.

Platinum uptake assay. The major goal of the experiment described here was to test if the cytotoxic responses produced by 1-3 in cancer cells correlate with the platinum content in cells. As Fig. 9 showed that complex 3 rapidly accumulated in cancer cells with a maximum platinum level reached after a $9 \mathrm{~h}$ incubation period, at this time point, the content of the hybrid agent is approximately 10 -fold higher than that determined for $\mathbf{1}$ and 2. As we expected, after tumor cells were treated with complexes, the content of $\mathbf{3}$ was strikingly higher than that of complexes $\mathbf{1}$ and 2 in cells, indicating that $\mathbf{3}$ was easily absorbed by tumor cells which may be related with its cationic feature. The results were in accordance with above biological activities.
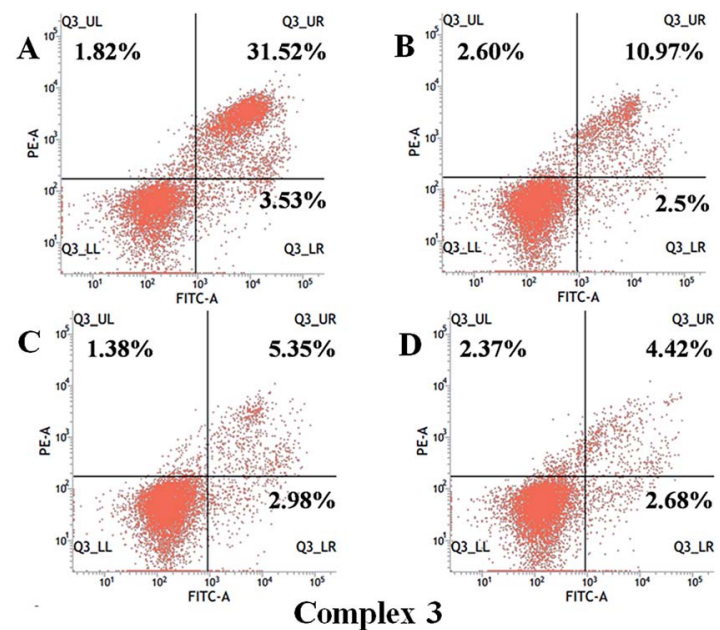

Fig. 7 The quantitative analysis of the proportion of viable, necrosis and apoptosis cells against HeLa cells after the treatment with 3 for $48 \mathrm{~h}$ at concentration of $0,2.5,5$, and $10 \mu \mathrm{M}$. 

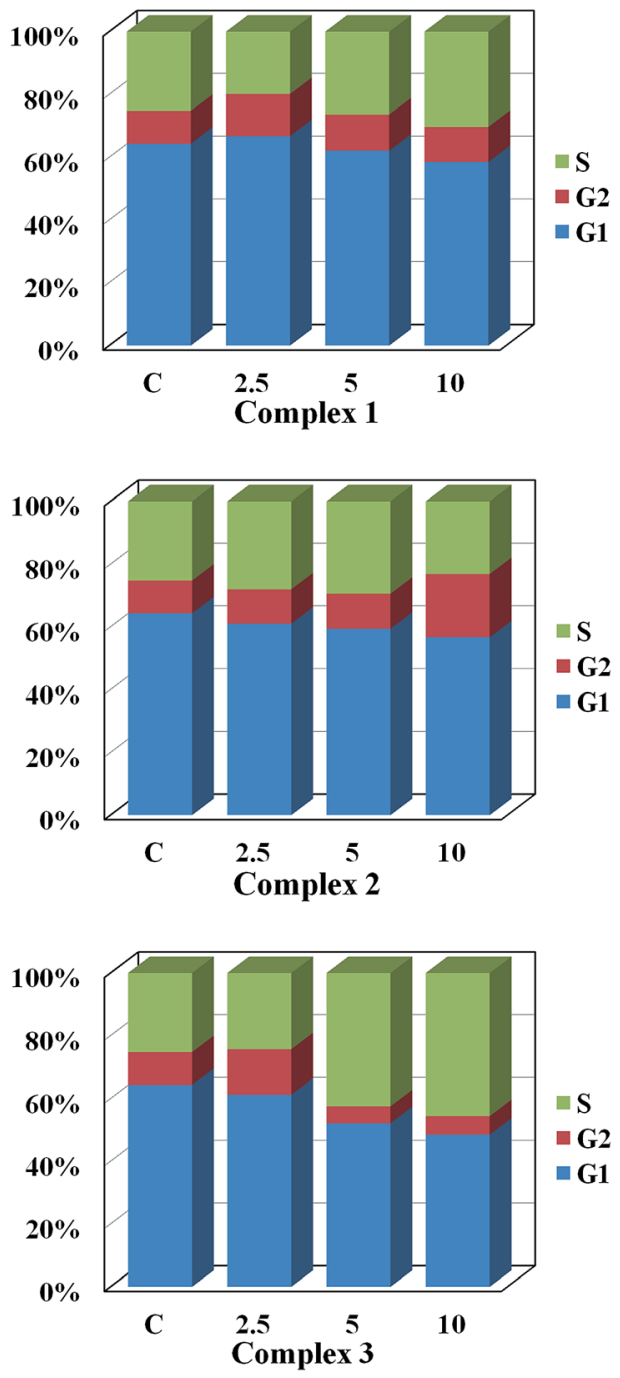

Fig. 8 Flow cytometric analysis of cell cycle distribution of HeLa cells treated with 1-3 for $48 \mathrm{~h}$ at the concentration of $0,2.5,5,10 \mu \mathrm{M}$.

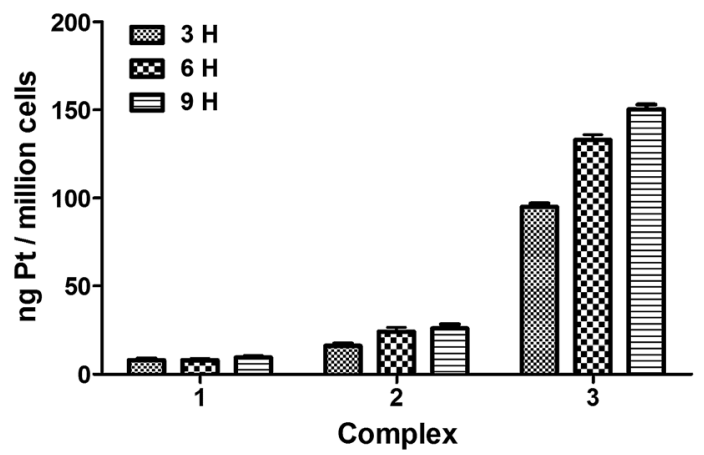

Fig. 9 Cellular platinum content in tumor cells treated with $4 \mu \mathrm{M}$ complexes $1-3$ for 3,6 , and $9 \mathrm{~h}$, respectively. The data are calculated through 3 duplicated experiments.

\section{Conclusions}

In this work, three new platinum(II) complexes [Pt(MH-TSC)Cl] (1), $\quad[\mathrm{Pt}(\mathrm{ME}-\mathrm{TSC}) \mathrm{Cl}] \quad(2)$ and $\left[\mathrm{Pt}(\mathrm{NH}-\mathrm{TSC})_{2}\right] \mathrm{Cl}$ (3) were synthesized and characterized. According to the results obtained from the HSA interaction experiments, we concluded that the fluorescence quenching mechanism of HSA by 1-3 might be a static binding process. Complexes 1-3, with monofunctional or cationic features, showed higher cytotoxic activity towards four tumor cell lines than that of cisplatin under the same condition, and also superior to other thiosemicarbazonebased metal complexes with similar structure published in literatures. ${ }^{37-39}$ Previous reports displayed that bi-ligand complexes like 3, exhibited prominent anticancer activity with an extra ligand changing physicochemical features such as planarity, hydrophobicity and coordination geometry of metal complex. ${ }^{40-42}$ Consistently, cationic complex 3 had a distinct transport manner, resulted in higher ability for cellular uptake, which might explain its superior cytotoxic activity. Comparing the structures of $\mathbf{1}$ and $\mathbf{2}$, we see that there is one primary amine $\left(-\mathrm{NH}_{2}\right)$ group for the ligand in $\mathbf{1}$, instead of secondary amine in 2, which might be available for hydrogen bonding with DNA base pairs and promising to improve the biological activity. So, it demonstrates that different transport manners or structural units will play a key role in the complexes' antiproliferative activity to cancer cells. In addition, the apoptotic study exhibited that complexes 1-3 could effectively induce apoptosis of HeLa cells. Meanwhile, cell proliferation assay demonstrated that treatments of HeLa cells with $\mathbf{1}$ and $\mathbf{3}$ hindered the cancer cells in S phase, while 2 processed a G2 phase arrest. These agents might trigger different signal pathways that eventually result in cell cycle arrest in different checkpoints. Further studies to elaborate its cytotoxicity mechanism are currently underway.

\section{Acknowledgements}

This work was supported by National Natural Science Foundation of China (No. 21371135), Tianjin Municipal Natural Science Foundation (Nos 13JCZDJC28200 \& 17JCZDJC33100).

\section{Notes and references}

1 T. C. Johnstone, K. Suntharalingam and S. J. Lippard, Chem. Rev., 2016, 116, 3436-3486.

2 D. Rades, D. Seidl, S. Janssen, A. Bajrovic, S. G. Hakim, B. Wollenberg and S. E. Schild, Oral Oncol., 2016, 57, 40-45.

3 M. Bandak, N. Jorgensen, A. Juul, J. Lauritsen, M. G. G. Kier, M. S. Mortensen and G. Daugaard, Eur. Urol. Focus, 2016, DOI: 10.1016/j.euf.2016.11.018.

4 Z. Xiao, C. Wang, L. Chen, X. Tang, L. Li, N. Li, J. Li, Q. Gong, F. Tang and J. Feng, Oncotarget, 2017, 8, 1329-1342.

5 X. Zhu, H. Shen, X. Yin, L. Long, C. Xie, Y. Liu, L. Hui, X. Lin, Y. Fang and Y. Cao, Oncogene, 2016, 35, 323-332.

6 E. Wong and C. M. Giandomenico, Chem. Rev., 1999, 99, 2451-2466.

7 L. Kelland, Nat. Rev. Cancer, 2007, 7, 573-584.

8 P. J. Loehrer, S. D. Williams and L. H. Einhorn, J. Natl. Cancer Inst., 1988, 80, 1373-1382.

9 K. S. Lovejoy and S. J. Lippard, Dalton Trans., 2009, 1065110659. 
10 J. Zhang, D. Liu, Y. Li, J. Sun, L. Wang and A. Zang, Mini-Rev. Med. Chem., 2009, 9, 1357-1366.

11 R. W. Brockman, J. R. Thomson, M. J. Bell and H. E. Skipper, Cancer Res., 1956, 16, 167-170.

12 K. Agrawal and A. Sartorelli, Prog. Med. Chem., 1978, 15, 321356.

13 M. Miller 3rd, C. Stineman, J. Vance, D. West and I. Hall, Anticancer Res., 1997, 18, 4131-4139.

14 C. A. Kunos, T. Radivoyevitch, S. Waggoner, R. Debernardo, K. Zanotti, K. Resnick, N. Fusco, R. Adams, R. Redline and P. Faulhaber, Gynecol. Oncol., 2013, 130, 75-80.

15 C. A. Kunos, T. Radivoyevitch, J. Pink, S. M. Chiu, T. Stefan, J. Jacobberger and T. J. Kinsella, Radiat. Res., 2010, 174, 574581.

16 K. Ishiguro, Z. P. Lin, P. G. Penketh, K. Shyam, R. Zhu, R. P. Baumann, Y. L. Zhu, A. C. Sartorelli, T. J. Rutherford and E. S. Ratner, Biochem. Pharmacol., 2014, 91, 312-322.

17 A. E. Stacy, D. Palanimuthu, P. V. Bernhardt, D. S. Kalinowski, P. J. Jansson and D. R. Richardson, J. Med. Chem., 2016, 59(10), 4965-4984.

18 E. M. Jouad, G. Larcher, M. Allain, A. Riou, G. M. Bouet, M. A. Khan and X. Do Thanh, J. Inorg. Biochem., 2001, 86, 565-571.

19 B. S. Holla, K. Malini, B. S. Rao, B. Sarojini and N. S. Kumari, Eur. J. Med. Chem., 2003, 38, 313-318.

20 J. Shao, W. G. Bao, H. Tian, B. Li, X. F. Zhao, X. Qiao and J. Y. Xu, Dalton Trans., 2014, 43, 1663-1671.

21 A. Castiñeiras, I. Garcia, E. Bermejo and D. X. West, Polyhedron, 2000, 19, 1873-1880.

22 M. Carcelli, D. Delledonne, A. Fochi, G. Pelizzi, M. C. Rodríguez-Argüelles and U. Russo, J. Organomet. Chem., 1997, 544, 29-35.

23 D. X. West, G. A. Bain, R. J. Butcher, J. P. Jasinski, Y. Li, R. Y. Pozdniakiv, J. Valdés-Martínez, R. A. Toscano and S. Hernández-Ortega, Polyhedron, 1996, 15, 665-674.

24 G. Sheldrick, Acta Crystallogr., Sect. E: Struct. Rep. Online, 1997, 1600-5368.
25 A. Spek, Acta Crystallogr., Sect. A: Found. Crystallogr., 1990, 46, c34-c34.

26 A. Ghezzi, M. Aceto, C. Cassino, E. Gabano and D. Osella, J. Inorg. Biochem., 2004, 98, 73-78.

27 J. Toneatto and G. A. Argüello, J. Inorg. Biochem., 2011, 105, 645-651.

28 P. Kandagal, S. Ashoka, J. Seetharamappa, V. Vani and S. Shaikh, J. Photochem. Photobiol., A, 2006, 179, 161-166.

29 F. Wang, W. Huang and Z. Dai, J. Mol. Struct., 2008, 875, 509514.

30 L. N. Hordge, K. L. McDaniel, D. D. Jones and S. O. Fakayode, Talanta, 2016, 152, 401-409.

31 M. B. Bolattin, S. T. Nandibewoor, S. D. Joshi, S. R. Dixit and S. A. Chimatadar, RSC Adv., 2016, 6, 63463-63471.

32 W. He, Y. Li, C. Xue, Z. Hu, X. Chen and F. Sheng, Bioorg. Med. Chem., 2005, 13, 1837-1845.

33 G. Zhang, Y. Wang, H. Zhang, S. Tang and W. Tao, Pestic. Biochem. Physiol., 2007, 87, 23-29.

34 J. Seo, B. Kim, D. N. Dhanasekaran, B. K. Tsang and Y. S. Song, Cancer Lett., 2016, 371, 30-37.

35 L. Sun and J. Fang, Cell Cycle, 2016, 15, 2647-2655.

36 G. Chandrasekher and D. Sailaja, Invest. Ophthalmol. Visual Sci., 2004, 45, 3577-3588.

37 M. Mohamed Subarkhan, R. N. Prabhu, R. Raj Kumar and R. Ramesh, RSC Adv., 2016, 6, 25082.

38 B. Q. Zou, X. Lu, Q. P. Qin, Y. X. Bai, Y. Zhang, M. Wang, Y. C. Liu, Z. F. Chen and H. Liang, RSC Adv., 2017, 7, 17923.

39 J. Shao, Z. Y. Ma, A. Li, Y. H. Liu, C. Z. Xie, Z. Y. Qiang and J. Y. Xu, J. Inorg. Biochem., 2014, 136, 13.

40 A. Li, Y. H. Liu, L. Z. Yuan, Z. Y. Ma, C. L. Zhao, C. Z. Xie, W. G. Bao and J. Y. Xu, J. Inorg. Biochem., 2015, 146, 52-60.

41 V. Gandin, M. Porchia, F. Tisato, A. Zanella, E. Severin, A. Dolmella and C. Marzano, J. Med. Chem., 2013, 56, 7416-7430.

42 C. Rajarajeswari, M. Ganeshpandian, M. Palaniandavar, A. Riyasdeen and M. A. Akbarsha, J. Inorg. Biochem., 2014, 140, 255-268. 